\title{
Recovery from Hurricanes and the Long-term Impacts on Perennial Tropical Fruit Crops in South Florida
}

\author{
Jonathan H. Crane and Bruce Schaffer \\ University of Florida, Tropical Research and Education Center, 18905 S.W. 280 Street, Homestead, \\ FL 33031-3314 \\ Richard J. Campbell \\ Fairchild Tropical Garden, 11935 Old Cutler Road, Miami, FL 33156
}

\begin{abstract}
Wind, flooding, and salinity stresses are the major environmental factors that cause damage during and immediately following a hurricane. However, in the days and months following a tropical storm or hurricane, heat, drought, and salinity stress increase in importance. High-velocity winds cause defoliation, defruiting, shoot, limb, and major scaffold limb breakage, trunk splitting and breakage, windthrow, and tree toppling (Brooks, 1946; Campbell et al., 1993; Crane et al., 1993a, 1993b; Loomis, 1946). Wind-throw is the complete uprooting of a tree, whereas with tree toppling, some portion of the roots remain in the ground. High-velocity winds also cause windthrown trees to impact other trees, and wind-blown debris, including rocks, to scarify tree bark.

Flooding caused by high rainfall or storm surges of fresh or salt water saturates the soil profile, reducing the ability of tree roots to anchor themselves in place against strong winds. Flood waters also act as a transport medium for biotic (i.e., other trees) and abiotic (e.g., inorganic debris) objects to hit standing trees, causing further uprooting, toppling, and scarification. Flooding also causes erosion of the soil and anoxic and anaerobic soil conditions (Schaffer et al., 1992). Depending upon the inherent tolerance of a species to flooded or continually saturated soil conditions, excessively wet, low-oxygen soil conditions during and after a hurricane may lead to root disease and/or reduced carbon assimilation. Salt-water intrusion caused by coastal storm surge and/or inland wind-blown salt spray usually impacts fruit trees physiologically through its osmotic effect on water relations and carbon assimilation (Schaffer and Andersen, 1994).

During the first days and weeks immediately following a hurricane, exposure of defoliated trees to high light and temperature results in
\end{abstract}

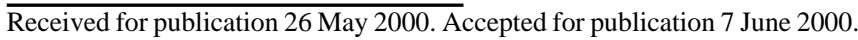
Florida Agricultural Experiment Station, Journal Series No. R-07049. The cost of publishing this paper was defrayed in part by the payment of page charges. Under postal regulations, this paper therefore must be hereby marked advertisement solely to indicate this fact. "sunburn" [i.e., overheating, damage, and death of exposed cambium tissues (Levitt, 1980)]. This also is associated with drought stress and nutrient deficiency of newly emerging leaves, a decline in tree vigor, and/or limb or tree death. Drought stress symptoms include wilting of newly emerged leaves and stems, leaf abscission, and stem dieback, as the demand for water by the developing canopy is greater than the capacity of the root system for water absorption. This is particularly true of trees subjected to saturated soil conditions (i.e., flooding and anaerobiosis) during the storm. Deposition of saline water in the soil profile during a storm leads to symptoms of salinity stress several days or weeks later. Symptoms may include leaf curling, tip and marginal leaf necrosis, reduced leaf expansion and abscission, stem and limb dieback, and tree death.

\section{IMPACT OF HURRICANE ANDREW ON TROPICAL FRUIT CROPS}

Seven years after Hurricane Andrew, nearly one-third of MiamiDade County's 8093 ha of tropical fruits has not been replanted. Tree damage and recovery varied among fruit species (Campbell et al., 1993; Crane et al., 1993b; Howard and Schokman, 1995). Heat stress resulting from complete defoliation of trees and subsequent constant high light intensity on exposed trunks and major scaffold limbs was minimal for avocado (Persea americana Mill.), 'Tahiti' lime (Citrus latifolia Tanaka), carambola (Averrhoa carambola L.), mamey sapote (Pouteria sapota Jacq.), guava (Psidium guajava L.), and longan (Dimocarpus longan Lour.). In contrast, mango (Mangifera indica L.) trees experienced severe heat-stress that led to necrosis and rotting of exposed trunks and limbs. Root damage caused by toppling and subsequent resetting of atemoya (Annona cherimola Mill. x A. squa$\operatorname{mos} a$ L.), mango, and grafted 'Tahiti' lime trees was severe; thus trees reset were less likely to recover than were trees left toppled or leaning. The resetting process presumably broke and/or further damaged those roots that remained in the ground. Extensive wood damage on all trees was followed by infestation of the bark by wood-boring insects. 
The extent and rate of recovery from hurricane-related wind stress varied among species. Avocado, carambola, guava, and longan refoliated within 3 to 4 weeks after Hurricane Andrew, and carambola and guava also flowered and produced fruit. In contrast, mango and atemoya trees went through two or more cycles of refoliating and dying back until the entire tree died. Over one-half of the mango and two-thirds of the atemoya acreage never recovered from Hurricane Andrew. Iron and nitrogen deficiencies commonly appeared in mango, atemoya, and guava. These species required more frequent foliar applications of micronutrients and soil-applied chelated iron after the hurricane than other fruit crops in the area.

Other consequences of hurricanes such as Andrew in south Florida include increased weed and vine growth and increased susceptibility to drought stress (because of lack of irrigation capability and reduced rooting). As trees recovered, branch breakage and root and trunk sprouting were common.

\section{HURRICANE DAMAGE AND RECOVERY OF SELECTED TROPICAL FRUIT CROPS IN SOUTH FLORIDA}

Avocado. Prior to Hurricane Andrew, Florida had $\approx 3480$ ha of bearing avocado trees (Federal State Market News Service, 1993). About 1174 ha was immediately lost due to the destruction by the hurricane or mechanical removal subsequent to it, leaving 2306 ha. Since $1993, \approx 303$ ha have been planted or replanted, bringing the current area under production to 2609 ha (Knodel, 1998).

A poststorm damage survey revealed that $87 \%$ of the avocado trees survived the storm in varying degrees of health; $13 \%$ were destroyed, $10 \%$ toppled, $10 \%$ stumped (trees reduced to a stump or stump plus major scaffold limbs), and 67\% left standing (Crane et al., 1993b). Multiple linear regression indicated that a significant $(P \leq 0.05)$ correlation $\left(R^{2}=0.47\right)$ existed between the number of trees that remained standing after the storm and tree age and height. As tree age increased and tree height decreased the number of trees left standing increased. We observed that orchards under a tree-size management program (i.e., topping and hedging) had much less damage than did nonpruned orchards. This may have been due to the reduced wind resistance of pruned trees. This was similar to observations after the hurricane of 1945 (Brooks, 1946).

West Indian avocado cultivars reportedly recovered much more slowly than did Guatemalan-type and hybrid types after the 1945 hurricane (Brooks, 1946). No pronounced differences in damage or recovery among avocado cultivars or races were observed after Hurricane Andrew, and 6 months later trees that were either left standing or reset recovered substantial canopy and bloomed (Campbell et al., 1993). The difference in the poststorm recovery after the $1945 \mathrm{vs.} 1992$ hurricane may be due in part to improved anchorage of the root system of trees growing in trenches versus being "flat" planted. The major soil type used for orchards in the Homestead, Fla., area is an oolitic limestone rock (Krome very gravelly loam and Chekika very gravelly loam) (Noble et al., 1996). Prior to the 1940s, fruit trees were commonly planted in shallow depressions or holes eked out of the rock; i.e., flat planted (Colburn and Goldweber, 1961). During the 1940s, heavy equipment began to be used and techniques were developed for scarifying the limestone soil to a depth of $10-15 \mathrm{~cm}$ and making trenches ( $46 \mathrm{~cm}$ wide and $46-61 \mathrm{~cm}$ deep) in rows corresponding to tree rows and spacing distances.

Recovery of avocado yields from Hurricane Andrew was relatively rapid (Fig. 1). Overall industry production during the 1998-99 season $(\approx 23,000 \mathrm{t})$ was only $20 \%$ less than that during the 1991-92 season $(\approx 28,000 \mathrm{t}$ ) when the commercial acreage was $25 \%$ greater (Florida Agricultural Statistics Service, 1999a). Much of this increase in yield efficiency may be attributed to reduced tree height and spread, the increased light exposure to previously nonproductive areas of the lower tree scaffold area, and reestablishment of productive canopy. Trees rapidly reestablished the "normal" phenological cycle and hurricane tree damage symptoms were almost nondetectable 7 years later (Table 1; Fig. 2). The only obvious signs of previous damage were the callus formation around broken-off or thinned-out scaffold limbs, occasional breakage of previously weakened branches, and small mounds of soil around the base of trees that toppled and were reset after the storm.

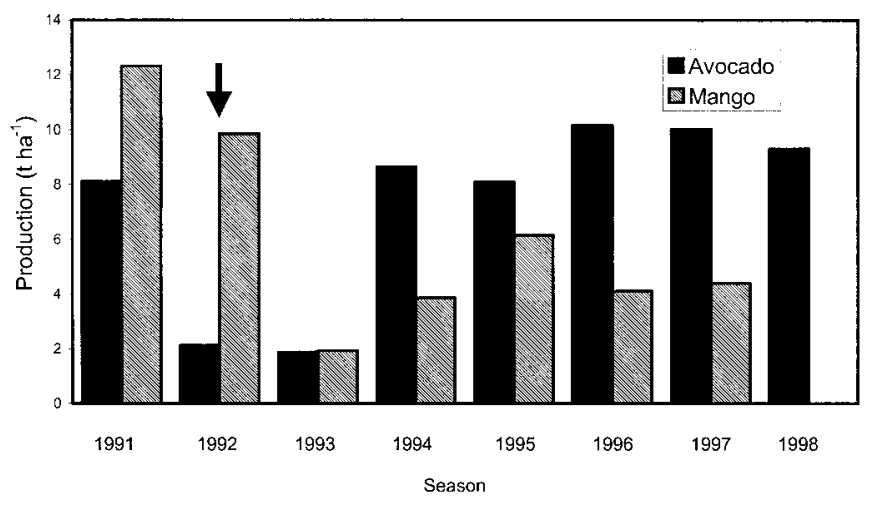

Fig. 1. Fruit production (t.hat ${ }^{-1}$ ) of Florida avocado from 1991to 1998 and mango from 1991 to 1997 after Hurricane Andrew (12 Aug. 1992). Hurricane Andrew (arrow) made landfall $\approx 2.5$ months into the avocado picking season (June through March) and during the last two to three weeks of the mango picking season (May through mid-September). Data for the 1992 season is not indicative of the production of early season cultivars. All other data reflect the industry average yield per hectare.

Table 1. Estimated rate and status of damage recovery of selected tropical fruit crops 7 years after hurricane Andrew (1992).

\begin{tabular}{|c|c|c|}
\hline Crop & $\begin{array}{l}\text { Rate of } \\
\text { recovery }\end{array}$ & 1999 tree recovery status \\
\hline Avocado & Rapid & $\begin{array}{l}\text { Evidence of tree damage minimal. Crop } \\
\text { yields at or above pre-hurricane levels. }\end{array}$ \\
\hline 'Tahiti' lime & Moderately rapid & $\begin{array}{l}\text { Evidence of tree damage still evident } \\
\text { in some trees. Yields per tree of surviving } \\
\text { trees near prehurricane levels. However, } \\
\text { these trees were beginning to decline or } \\
\text { had declined from their most productive } \\
\text { period ( } 25 \text { years). }\end{array}$ \\
\hline Mango & Slow to moderate & $\begin{array}{l}\text { Evidence of heat stress and root damage } \\
\text { still present in some trees. However, } \\
\text { most trees appeared to have made a "full" } \\
\text { recovery. }\end{array}$ \\
\hline Carambola & Rapid & $\begin{array}{l}\text { Evidence of tree damage minimal. Tree } \\
\text { crop yields at or above pre-hurricane } \\
\text { levels. }\end{array}$ \\
\hline Lychee & Slow to moderate & $\begin{array}{l}\text { Evidence of hurricane damage variable. } \\
\text { Most trees surviving the storm had } \\
\text { recovered well. Crop yields appeared to } \\
\text { be more affected by current weather } \\
\text { patterns than any damage sustained } \\
\text { during the } 1992 \text { hurricane. }\end{array}$ \\
\hline Longan & Moderate to rapid & $\begin{array}{l}\text { Evidence of tree damage minimal. Crop } \\
\text { yields appeared to be more affected by } \\
\text { current weather patterns than any damage } \\
\text { sustained during the } 1992 \text { hurricane. }\end{array}$ \\
\hline Mamey sapote & Slow to moderate & $\begin{array}{l}\text { Some evidence of tree damage (e.g., } \\
\text { stumped main trunk). In some cases, } \\
\text { resumption of "normal" cropping took } 4 \\
\text { to } 5 \text { years. Recovery has been good. }\end{array}$ \\
\hline Guava & Rapid & $\begin{array}{l}\text { Some minimal evidence of tree damage, } \\
\text { i.e., leaning tree trunks. Yields appear } \\
\text { normal. }\end{array}$ \\
\hline Atemoya & $\begin{array}{l}\text { Rapid during first } \\
6-12 \text { months, then } \\
\text { very slow }\end{array}$ & $\begin{array}{l}\text { Evidence of root damage is still evident } \\
\text { in some trees. Tree recovery is variable, } \\
\text { however, some trees have made a } \\
\text { moderate recovery. }\end{array}$ \\
\hline
\end{tabular}

'Tahiti' lime. 'Tahiti' lime area in Florida decreased from 2671 ha prior to Hurricane Andrew (1992) to 904 ha immediately after the hurricane (Federal State Market News Service, 1993), a direct loss of 1766 ha. About 378 ha have been planted or replanted since 1993, bringing the 1999 area under production to 1282 ha (Knodel, 1998a).

After the 1945 hurricane, Brooks (1946) observed that damage to budded trees varied with rootstock. Trees budded onto rough lemon (C. jambhiri Lush.) had more damage and toppled more than did trees budded on grapefruit (C. paradisi Macf.). However, we did not observe dramatic rootstock effects or damage after Hurricane Andrew. This may be because the use of grapefruit as a rootstock was discontinued many years ago and/or that rough lemon and macrophylla $(C$. 

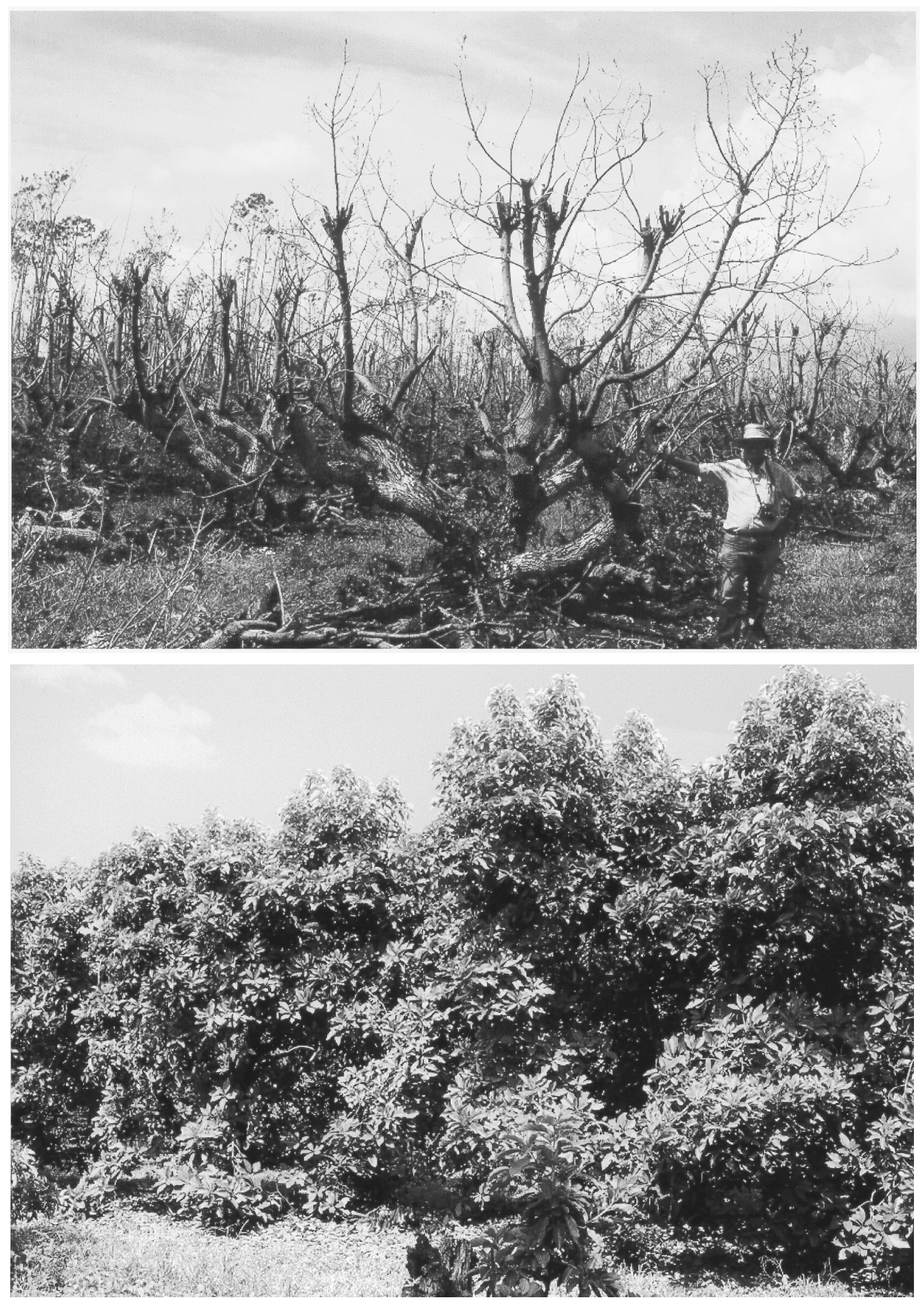

Fig. 2. Damage to an avocado orchard immediately after Hurricane Andrew (top, 24 Aug. 1992) and a similar orchard showing complete recovery from the storm 7 years later (bottom).

macrophylla Wester) rootstocks present during Hurricane Andrew behaved similarly.

The damage sustained by lime trees during Hurricane Andrew varied with method of propagation-budding or air layering (marcottage) (Crane et al., 1993b). Since virtually all orchards were regularly topped at 2 to $2.5 \mathrm{~m}$, tree height did not appear to be a factor in tree survival and damage. The percentage of trees that remained upright in orchards of budded trees on C. macrophylla and C. jambhiri rootstocks $(65 \%$ to $66 \%$ ) was greater than that in orchards planted with air-layered trees (9\%) (Crane et al., 1993b). Only 4\% to $7 \%$ of the former were destroyed vs. $83 \%$ of the latter. Trees propagated by air layering literally blew away during the storm. Interestingly, in orchards planted with alternating trees of budded and air-layered trees, the percentages of trees destroyed $(11 \%)$ and of those that remained upright $(61 \%)$ were similar to those in orchards planted with only budded trees. Six to 12 months after Hurricane Andrew orchards with mostly bud-propagated trees had refoliated and there was some renewed fruit production (Crane et al., 1993a). However, rootstock sprouting (mostly Citrus jambhiri and C. macrophylla) was prevalent, and some trees declined because of excessive exposure of the trunk and major limbs to the sun. Trunk and root rots were also evident. Symptoms of $\mathrm{Fe}$ and $\mathrm{Mg}$ deficiencies were observed in leaves of some trees that sustained root and/or trunk damage. However, nutrient deficiencies did not appear to be a major problem in surviving trees.

In 1999 , we estimated that perhaps $80 \%$ of the lime trees that withstood Hurricane Andrew had recovered well from the damage. However, many of the trees that toppled (21\% to $29 \%$ ) during the storm remained tilted 7 years later (Table 1). In some cases, trees left 
toppled or leaning recovered better than those that were reset. Many others showed callus formation around broken-off or thinned-out scaffold limbs and small mounds of soil around their base; evidence they had toppled and were reset after the hurricane.

Estimates of the fruit production by surviving trees were difficult as no data were available. However, most of the surviving trees appeared to have recovered slowly and in 1999 produced moderate crops (i.e., 150-200 kg per tree). The typical phenological cycle for limes appeared to reestablish rather quickly after Hurricane Andrew, perhaps due to the strong synchronizing effect of low winter temperatures on vegetative and reproductive growth patterns. Overall, lime production has increased slowly, as young orchards take 6 to 10 years to reach full production and orchards planted with budded trees prior to Hurricane Andrew were near the end of their productive life-span (Campbell, 1979; Florida Agricultural Statistics Service, 1999a, 1999b). In addition, foreign competition, which supplied the United States with 'Tahiti' limes during the past 7 years, has continued and has had a somewhat negative effect on replanting.

Mango. The Florida mango industry suffered a dramatic decline because of Hurricane Andrew. Planted area went from 1012 ha in 1991-92 to 648 ha in 1992-93 (Florida Agricultural Statistics Service, 1997). A further reduction in the planted area to $\approx 567$ ha has occurred because of foreign competition, orchard abandonment, replanting with other crops, and urbanization.

Mango trees withstood the hurricane of 1935 with only moderate damage (Wolfe, 1936), whereas they were more severely damaged than most other tropical fruit trees during the 1945 hurricane (Brooks, 1946). Similarly, nearly one-third (29\%) of the mango trees were destroyed during Hurricane Andrew (1992) with $21 \%$ reduced to stumps, $20 \%$ toppled, and $30 \%$ remaining upright (Crane et al., 1993b). As with avocado, multiple linear regression analysis indicated a significant $(P \leq 0.05)$ correlation $\left(R^{2}=0.67\right)$ between the percentage of trees that remained standing after the hurricane and tree age and height. As tree age increased and tree height decreased the percentage of mango trees standing after the hurricane increased. As with avocado orchards, we observed that those orchards under a tree size management program had less damage and more tree survival than those not managed.

Six months after Hurricane Andrew, some mango trees left standing and reset had recovered substantial canopy while others were declining (Campbell et al., 1993). Symptoms of Fe and Zn deficiency were prevalent in many trees. In general, during the first 5 years after the storm, canopy recovery and fruit production were reestablished relatively slowly (Florida Agriculture Statistics Service, 1999a; Fig. $1)$. Some trees continued to show symptoms of deficiencies of $\mathrm{Fe}$ and $\mathrm{Zn}$. A reassessment of mango tree recovery in 1996 (4 years after Hurricane Andrew) indicated that $20 \%$ of the surviving trees continued to decline because of previous heat stress and root damage (Crane and Balerdi, 1996). Evidence of continued damage included woodrotting fungi along previously heat-stressed areas of the trunk and limbs, leaf nutrient deficiencies, and sparse canopies. Seven years after the hurricane (1999), an estimated $25 \%$ of the remaining mango trees still showed the effects (e.g., sparse canopy, dieback, leaf nutrient deficiencies) of excessive exposure to the sun and wood and root damage (Table 1; Fig. 3). The inherent heat stress tolerance of the trunk and major scaffold limb areas of mango trees appears to be lower than that of other fruit crops such as avocado.

Overall mango production in the area has increased slowly during the past 5 years, but is expected to decrease, as foreign competition (encouraged by the North American Free Trade Agreement) has been and continues to be very intense. As a result, the remaining Florida mango growers are pursuing specialty markets in which they are competitive (Crane and Balerdi, 1996).

Carambola. Prior to Hurricane Andrew, Florida had at least 176 ha of carambola (Crane, 1989), and perhaps as little as 14 ha were lost because of the hurricane. In 1999, there was an estimated 162 ha of carambola in south Florida.

After the 1935 hurricane, carambola trees were reported to have weak branches and sustained substantial damage (Wolfe, 1936). In contrast, a survey made after Hurricane Andrew indicated that $93 \%$ of the carambola trees survived, with $13 \%$ toppled, $4 \%$ reduced to

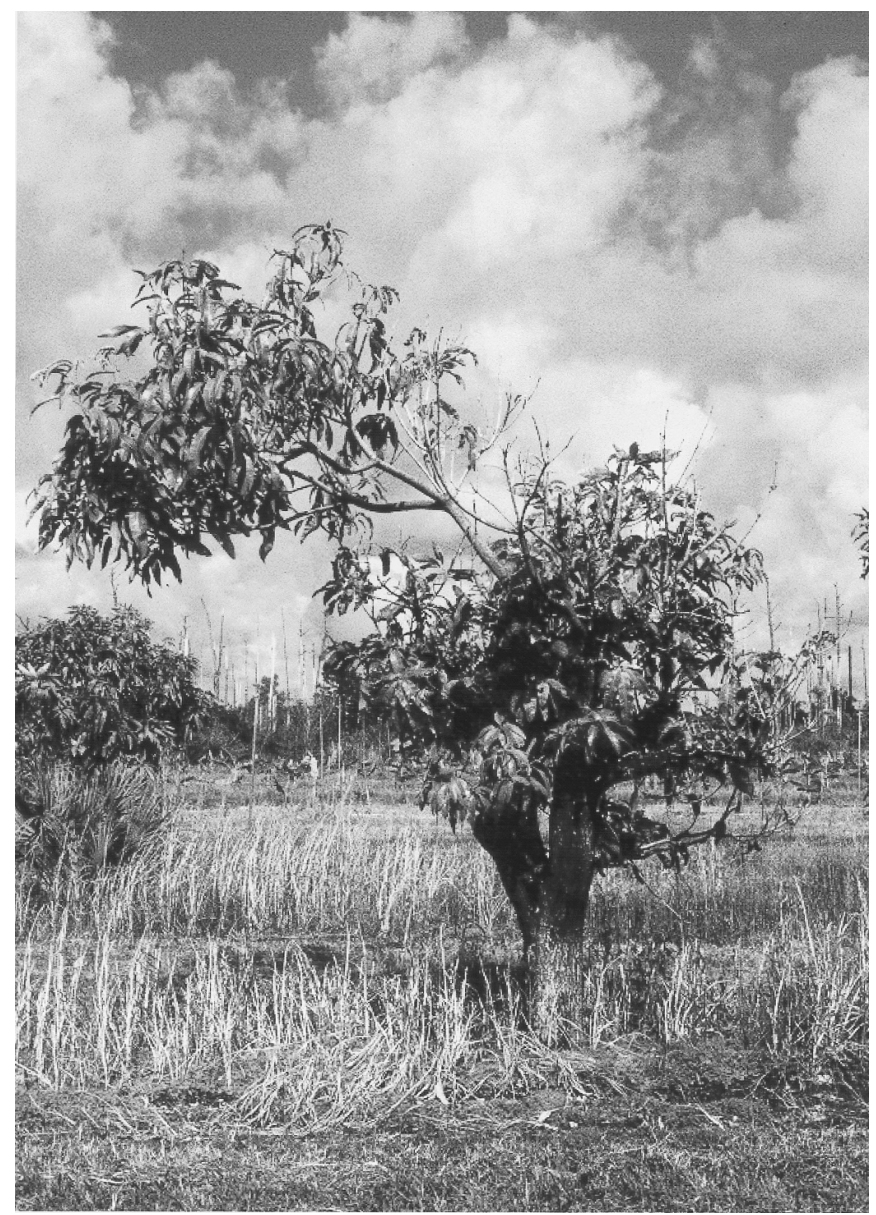

Fig. 3. A declining mango tree 7 years after Hurricane Andrew (24 Aug.1992).

stumps, and $76 \%$ remaining upright (Crane et al., 1993b). This difference in observed damage after the 1935 and 1992 hurricanes may be due in part to improved anchorage of the root system of trees growing in trenches vs. being "flat" planted as described previously for avocado, and that pruning for tree size control was probably more common in 1992 than in 1935.

Simple linear regression analysis indicated significant $(P \leq 0.05)$ correlations between the percentage of trees that remained upright vs. tree age $\left(R^{2}=0.69\right)$ and a negative correlation vs. tree height $\left(R^{2}=-0.76\right)$. The high percentage of surviving trees may have been due to the willowy or flexible growth habit of the trees, which quickly defoliated and defruited during the hurricane and offered little resistance to the wind. Trees that were severely damaged declined over the next 12 months. Crane et al. (1994a) attributed the decline and death of 4-yearold 'Arkin' carambola trees on 'Golden Star' and M-18960 rootstocks 13 to 14 months after Hurricane Andrew to bark detachment and breakage of major roots.

A pronounced flowering occurred within 3 to 4 weeks after the storm but resulted in little to no fruit set; however, a second bloom occurred 3 to 4 weeks later and a good crop set (Campbell et al., 1993; Crane et al., 1993a). Phenologically, the complete defoliation of the trees resulted in an off-season bloom and a very early harvest. Subsequently, trees reestablished their "normal" vegetative (April/ May through October) and reproductive cycle with two harvest periods (September-October and December-January) (Nuñez-Elisea and Crane, 1999).

Little evidence of damage existed 7 years after Hurricane Andrew (Table 1). As with avocado trees, wound healing of limbs pruned after the storm, and mounding of soil around the base of trees that toppled, and were reset after the storm, were the main evidence of storm damage. However, some trees still lean.

Lychee. Prior to Hurricane Andrew, the area of lychee production in Florida was estimated at 101 ha. There were two major cultivars, 
'Mauritius' (45\% of the area) and 'Brewster' (55\%). Direct loss of lychee trees due to the destruction from the storm or subsequent removal was $\approx 41$ ha. Since 1993 , an estimated 190 ha have been planted, bringing the area under production to 251 ha in 1999.

Lychee trees sustained little damage after the 1935 hurricane (Wolfe, 1936). A posthurricane damage survey reported dramatic differences in the damage sustained by 'Brewster' vs. 'Mauritius' trees (Crane et al., 1993b). The percentages of trees destroyed by the hurricane were $40 \%$ for 'Brewster' vs. 53\% for 'Mauritius', and many more 'Mauritius' (29\%) than 'Brewster' trees $(2 \%)$ were reduced to stumps. Fewer 'Mauritius' (16\%) than 'Brewster' trees (58\%) remained standing. Regression analysis indicated significant $(P \leq 0.05)$ correlations between tree age and survival $\left(R^{2}=0.42\right)$ and tree height and survival $\left(R^{2}=-0.58\right)$. Like avocado and mango, trees under a tree size management program were damaged less than those not managed. This difference in the degree of damage among cultivars is probably due to the proclivity of 'Mauritius' to form narrow crotch angles with occluded bark, leading to limb breakage under physical stress (e.g., wind, ice-loading, and heavy fruit loads).

Six months after the hurricane, some lychee trees left standing and reset were slowly recovering canopy, whereas others that had initiated new growth were dying back (Campbell et al., 1993; Crane et al., 1993a). Some trees (perhaps 5\%) appeared to have been slowly declining during the 7 years following the hurricane, perhaps because of damage to major roots and/or cambium. Fruit production was greatly reduced 1 to 2 years after the hurricane. However, subsequent production of most surviving trees has been "normal." Trees appeared to establish their phenological cycle within 1 to 2 years after the storm because of low soil moisture and winter temperatures, which synchronized vegetative and reproductive growth. In general, there was no pronounced evidence of hurricane damage to most trees 7 years after the hurricane (Table 1). Some trees showed signs of wound healing and soil mounding from the resetting process.

Longan. Florida's longan acreage was estimated at 30 ha prior to Hurricane Andrew. A loss of $\approx 30 \%$ of the trees due to the destruction from the hurricane or subsequent tree removal reduced this to $\approx 20$ to 25 ha (Crane et al., 1993b). Between 1993 and 1999, an estimated 137 ha have been planted, bringing the estimated area under production in 1999 to 162 ha.

An estimated $70 \%$ of the longan trees survived Hurricane Andrew (Crane et al., 1993b). Only a small percentage toppled (2\%), but $28 \%$ were reduced to stumps. Survival was negatively correlated $(P \leq 0.05)$ with tree age and positively correlated with tree height $\left(R^{2}=0.56\right)$. No obvious explanation can be offered for this incongruous finding. Longan trees are vegetatively propagated by air layering, and there was little routine tree height control in most longan orchards prior to Hurricane Andrew.

Six months after Hurricane Andrew, surviving longan trees were making a slow to moderate recovery, while perhaps $10 \%$ to $20 \%$ of the trees that had initiated new growth were dying back (Campbell et al., 1993; Crane et al., 1993a). In contrast with lychee, there was no prolonged tree decline. Most longan trees either made a full recovery or were dying or being removed within 18 months after the hurricane. Interestingly, sprouting from damaged roots of air-layered longan trees resulted in multi-trunked trees. As with lychee, fruit production was reduced 1 to 2 years after the hurricane. However, trees subsequently recovered the "normal" phenological cycle of vegetative and reproductive growth. In general, there was no pronounced evidence of damage on most trees 7 years after the hurricane (Table 1), but some trees showed signs of wound healing and soil mounding from resetting.

Mamey sapote. Prior to Hurricane Andrew, Florida had about 108 ha of mamey sapote (Crane, 1989) and perhaps as little as 7 ha were lost due to the hurricane. In 1999, there was an estimated 125 ha.

A post-Hurricane Andrew storm damage survey found $84 \%$ of the mamey sapote trees survived, with an estimated $1 \%$ toppled, $44 \%$ reduced to stumps, and 39\% remaining upright (Crane et al., 1993b). Sixteen percent of the trees were destroyed. Many trees were reduced to stumps (i.e., lost their major scaffold limbs) - more than any of the other fruit crops surveyed. We attributed this to the tension placed upon the limbs and the tendency for mamey sapote to produce three to four weakly attached limbs within close proximity of one another along the trunk. Similarly, mamey sapote limbs break from the weight of heavy fruit loads prior to harvest or ice build-up during cold protection with high-volume irrigation. This scaffold limb loss may also explain why so few mamey sapote trees toppled and were reduced to stumps. Multiple linear regression indicated that the percentage of trees that survived $(84 \%)$ increased significantly $(P \leq 0.05)$ with tree age and decreased significantly with tree height $\left(R^{2}=-0.43\right)$. This finding reinforces the observation that the trunk and major limbs of older trees are more stable against strong winds than are those of young trees. In contrast, the wind resistance of tall trees increases their chances of damage, such as toppling and uprooting, when exposed to strong winds.

Two months after Hurricane Andrew many mamey sapote trees were vigorously flushing and some were blooming (Campbell et al., 1993). Six months after the hurricane, trees were continuing vigorous vegetative growth (Crane et al., 1993b). However, some trees grew vegetatively for 4 to 5 years before resuming reproductive growth. Seven years after the storm, evidence of damage could readily be seen where regrowth from stumped trees occurred (Table 1). Many hurricane-damaged branches and weak new limbs have been observed breaking since 1992 .

Guava. The 31 ha of commercial guavas in Florida during 1992 did not suffer severe damage from Hurricane Andrew. The area of production basically remained about the same after the storm and had increased to $\approx 81$ ha by 1999 .

Eighty-four percent of the guava trees survived Hurricane Andrew, with $69 \%$ of the trees standing upright after the storm (Crane et al., 1993b). This can be attributed to the commercial practice of regularly topping trees at 2.1 to $2.7 \mathrm{~m}$, their strong wood, vigorous root growth, and the resulting high root-to-shoot ratio. Tree survival was positively correlated $(P \leq 0.01)$ with increasing tree age and negatively correlated with tree height $\left(R^{2}=-0.75\right)$. Interestingly, most guava trees and the majority of 'Tahiti' lime trees that were present during Hurricane Andrew were propagated by airlayering and regularly pruned to similar heights. However, guava trees sustained much less damage than did 'Tahiti' lime trees. This may be due to the much stronger wood and vigorous root system of air-layered guava compared with those of 'Tahiti' lime trees.

Guava trees began regrowth immediately after Hurricane Andrew and flowered and set a crop within 2 months (Campbell et al., 1993; Crane et al., 1993b). Six to 7 months after the hurricane some fruit was harvested. Leaf Fe deficiency symptoms were common on the new flush of many trees after the hurricane and may have resulted from lack of fertilization and/or root damage. However, trees appeared to reestablish their phenological cycle rapidly after initial defoliation and wood damage. As with longan, sprouting from damaged roots of airlayer propagated trees resulted in multi-trunked trees. Seven years after the hurricane, most guava trees had recovered well (Table 1). The most common evidence of hurricane damage was leaning of trunks of some trees.

Atemoya. The Florida atemoya industry suffered a dramatic decline in area due to Hurricane Andrew, going from 61 ha in 1992 to an estimated 30 ha after the storm. A further reduction in the planted area from 1992 to 1999, due to poor productivity, orchard abandonment, and replanting with other crops, resulted in $\approx 7$ ha remaining.

Various species of Annona trees sustained substantial damage during the 1935 hurricane (Wolfe, 1936). A survey in 1993 estimated that only $\approx 10 \%$ of the atemoya trees destroyed outright by Hurricane Andrew; however, $77 \%$ of the trees toppled (Crane et al., 1993b). The high percentage of tree survival was probably due to the practice of pruning trees to a 3.6- to 4.6- $\mathrm{m}$ height. In contrast, the high percentage of tree toppling may have been due to high wind resistance of the globose-shaped tree canopy and relatively low root-to-shoot ratio.

Atemoya trees appeared to make slow to moderately rapid regrowth immediately after Hurricane Andrew. However, this new regrowth usually became chlorotic and eventually died back. One or more cycles of new flush and shoot growth and then dieback occurred over the next 18 to 24 months. This was common in trees that were leaning or toppled during the storm and reset afterward. Observations suggested that initial root damage caused by the storm was aggravated 
by the resetting process; i.e., more roots were broken or damaged during the process. Over the next 7 years many surviving atemoya trees never resumed "normal" fruit production, remaining vegetative and in some cases in a state of decline (Table 1). In addition, low yields and the expense of fruit production has had a negative effect on replanting. This led to the removal of numerous orchards.

\section{SUMMARY}

Recovery of tropical fruit crops from hurricane damage varies among species. Avocado, carambola, and guava recovered canopy and fruit production rapidly after Hurricane Andrew in 1992, while mango and atemoya did not appear to recover for 18 to 36 months. Recovery time of lychee, longan, mamey sapote, and 'Tahiti' lime appeared to be intermediate.

Previous and recent observations after hurricanes demonstrated differences in tolerance and recovery among fruit crops based on tree size and age, propagation method (budded vs. air layering), and tolerance of exposed wood to high sunlight after the storm. Based upon past and recent observations, recommendations to prepare for and recover from hurricanes for tropical fruit crops have been made (Crane et al., 1994b). These include selection of wind-protected sites, preplant trenching of the soil to facilitate root extension, use of grafted or budded trees of some species (i.e., 'Tahiti' lime), and a regular tree size control program to reduce wind resistance. Posthurricane practices include protecting trunks and limbs from exposure to direct sunlight as quickly as possible, thinning out of the canopy of root damaged trees to reduce the transpirational load as quickly as possible, and resetting of some species but not others, reestablishment of the irrigation system as quickly as possible, good weed and vine control, use of mulch to retain soil moisture, and resumption of modified fertilizer applications.

\section{Literature Cited}

Brooks, J.R. 1946. Hurricane damage to commercial fruit trees in Dade County. Proc. Fla. State Hort. Soc. 59:149-151.

Campbell, C.W. 1979. Tahiti lime production in Florida. Bul. 187. Univ. of Florida, IFAS, Florida Coop. Ext. Serv., Gainesville.

Campbell, R.J., C.W. Campbell, J. Crane, C. Balerdi, and S. Goldweber. 1993. Hurricane Andrew damages tropical fruit crops in south Florida. Fruit Var. J. 47:218-225.

Colburn, B. and S. Goldweber. 1961. Preparation of oolitic limestone soil for agricultural use. Proc. Fla. State Hort. Soc. 74:343-344.

Crane, J.H. 1989. Acreage and plant densities of commercial carambola, mamey sapote, lychee, longan, sugar apple, atemoya, and passion fruit plantings in south Florida. Proc. Fla. State Hort. Soc. 102:239-242.

Crane, J.H., A.J. Dorey, R.C. Ploetz, and C.W. Weekly, Jr. 1994a. Posthurricane Andrew effects on young carambola trees. Proc. Fla. State Hort. Soc. 107:338-339.

Crane, J.H. and C.F. Balerdi. 1996. Effect of hurricane Andrew on mango trees in Florida and their recovery. Acta Hort. 455:323-330.

Crane, J., C. Balerdi, R. Campbell, C. Campbell, and S. Goldweber. 1993a. Hurricane Andrew and south Florida's tropical fruit crops industry. The Florida Grower and Rancher 86:25-27.

Crane, J., C. Balerdi, R. Campbell, C. Campbell, and S. Goldweber. 1994b. Managing fruit orchards to minimize hurricane damage. HortTechnology 4:21-27.

Crane, J.H., R.J. Campbell, and C.F. Balerdi. 1993b. Effect of hurricane Andrew on tropical fruit trees. Proc. Fla. State Hort. Soc. 106:139-144.

Federal-State Market News Service. 1993. Marketing Florida tropical fruits and vegetables: Summary 1992-93. Federal-State Market News Serv., Orlando.

Florida Agricultural Statistics Service. 1997. Tropical fruit: Production and value, 25 Apr. 1999. Florida Agr. Stat. Serv., Orlando.

Florida Agricultural Statistics Service. 1999a. Tropical fruit: Production and value, 23 Apr. 1999. Florida Agr. Stat. Serv., Orlando.

Florida Agricultural Statistics Service. 1999b. Tropical fruit: production and value, 24 Apr. 1999. Florida Agr. Stat. Serv., Orlando.

Howard, R.A. and L. Schokman. 1995. Recovery responses of tropical trees after hurricane Andrew. Harvard Papers in Bot. 6:37-74.

Knodel, G.A. 1998a. Lime Administrative Committee annual report, 1997-98 season, Marketing Order No. 911. Lime Administrative Comm., Homestead, Fla.

Knodel, G.A. 1998b. Avocado Administrative Committee annual report, 1997-1998 season, Marketing Order No. 915. Avocado Administrative Comm., Homestead, Fla.

Levitt, J. 1980. Responses of plants to environmental stress. vol. I. Chilling, freezing and high temperature stresses. Academic, New York.

Loomis, H.F. 1946. Hurricane damage to tropical plants. Proc. Fla. State Hort. Soc. 59:146-149.

Noble, C.V., R.W. Drew, and J.D. Slabaugh. 1996. Soil survey of Dade County area, Florida. U.S. Dept. Agr. and Natural Resources Cons. Serv.

Nuñez-Elisea, R. and J.H. Crane. 1999. Phenology, shoot development, and floral initiation of carambola (Averrhoa carambola L. cv. Arkin) in a subtropical environment. Proc. Fla. State Hort. Soc. 111:310-312.

Schaffer, B., P.C. Andersen, and R.C. Ploetz. 1992. Responses of fruit crops to flooding. Hort. Rev. 13:257-301.

Schaffer, B. and P.C. Andersen. 1994. Handbook of environmental physiology of fruit crops. vol. II: Sub-tropical and tropical crops. CRC Press, Boca Raton, Fla.

Wolfe, H.S. 1936. Effects and after-effects of hurricanes on sub-tropical fruits. Proc. Fla. State Hort. Soc. 49:123-125. 